\title{
Isolation and quantification of microorganisms from some common milk products within Dhaka city, Bangladesh
}

\author{
Mushfia Malek, Jasmin Akter, Tasnia Ahmed and Md. Aftab Uddin* \\ Department of Microbiology, Stamford University Bangladesh, 51 Siddeswari Road, Dhaka-1217, \\ Bangladesh
}

Received 28 February 2015/Accepted 20 April 2015

\begin{abstract}
While milk is well known to be a balanced diet with its high nutritional values, conversely milk and milk products may serve as potential substrate for the growth and proliferation of a range of microorganisms which in turn fatally influences mass public health. Current study attempted to examine the likelihood of microbial contamination within some common milk products consumed by the locality of the city of Dhaka, Bangladesh. All samples exhibited the presence of bacterial and fungal contamination within a range of $10^{2}-10^{4} \mathrm{cfu} / \mathrm{mL}$ and $10^{2}-10^{3} \mathrm{cfu} / \mathrm{mL}$, respectively. Among specific pathogens, Staphylococcus spp. was noticed to be the predominant ones and was recovered from 9 samples out of 20 samples in a range of $10^{2}-10^{3} \mathrm{cfu} / \mathrm{mL}$. Klebsiella spp. and Vibrio spp. were found within 6 and 9 samples, respectively. Products were also found to be contaminated with Vibrio spp. Study of antibiotic susceptibility test revealed that all the pathogenic bacteria were resistant against most of the commonly used antibiotics of which several isolates showed multi-drug resistant (MDR) trait. Therefore, the presence of pathogenic bacteria with the drug-resistance property in tested milk and milk products overall imparted the necessity of maintaining standardized hygienic handling and processing means for better management of public health.
\end{abstract}

Key words: Milk; Bacteria; Fungi; Quality; Drug resistance

Milk has long been known to be the most nutritious as well as balanced food being rich in proteins, fats, carbohydrates, vitamins, minerals, essential amino acids, etc. (1). However, milk may serve as an ideal substrate for the growth and survival of an array of bacteria and fungi, thereby leading to the public health threat (2-9). Microorganisms present in milk and milk products may influence the flavour, taste and texture of the finished forms of foods (10). Usually, the lactic acid bacteria (LAB; i.e., Lactococcus, Lactobacillus, Leuconostoc, Streptococcus and Enterococcus) are the dominant microbial population in bovine, goat, sheep and buffalo milk, which are usually available prior to pasteurization (10). Psychrotrophic microbial populations, which particularly establish themselves during cold storage, are also a major component and frequently include Pseudomonas and Acinetobacter spp. (11-13). Undesirable microorganisms including Gram negative psychrotrophs such as Pseudomonas spp., Achromobacter spp., Aeromonas spp., Serratia spp., Alcaligenes spp., Chromobacterium spp., Salmonella spp., Brucella spp., Mycobacterium bovis, Listeria monocytogenes and Campylobacter jejuni, Flavobacterium spp. and yeasts such as Candida spp., can cause spoilage and hence render the raw or even the processed milk unsuitable for human consumption (14,

${ }^{*}$ Corresponding Author: Mailing address. Md. Aftab Uddin, Department of Microbiology, Stamford University Bangladesh, 51 Siddeswari Road, Dhaka 1217, Bangladesh. E- mail: aftab_mb12@yahoo.com.
15).

Indeed, milk borne pathogenic microorganisms have been globally well reported to trigger various disease outbreaks resulting in fatality $(1,16-18)$. Microorganisms may gain access into milk and milk products from a variety of sources, including the milking apparatus, surrounding air condition, soils, water or moisture content, etc. $(1,19,20)$. The bovine teat surface is known to harbor varieties of bacteria $(19,21,22)$. Moreover, the unhygienic handling from the operators may largely account for the microbial contamination of milk.

Contamination of milk and milk products by pathogenic microorganisms is a global health concern; however, its fatal impact on human and animal health in the developing countries including in Bangladesh has not yet been extensively resolved except a few research works $(1,14)$. Since the constituents of milk and milk based products are adequate enough to support the microbial growth and replication, the dairy foods intensely demand a careful microbiological examination for the quality assurance for the sake of consumer safety. Some of the previous local researches within Dhaka city, Bangladesh revealed that raw or un-pasteurized milk and milk products could be very efficient vehicle for bringing a large number of people into contact with potential microbial hazards with an ultimate effect in the onset of various diseases $(1,14$, 15). Therefore, the safety of milk products in context to the onset of food borne diseases stands as a major global health issue, especially in the developing countries where production of milk and milk product usually takes place 
under poor hygienic practices $(14,15)$. Moreover, food contamination with antibiotic-resistant bacteria is a major threat to public health, as the antibiotic resistance determinants can be transferred to other bacteria of human clinical significance (23-25). Certain antibiotics, however, are critical to human medicine because there is no other drugs available to treat human infections caused by multi drug resistant pathogens (26-28). Current study further endeavored to chalk out the microbial content with demonstration of their drug resistant traits within some popular consumable milk products within the community inhabiting the city of Dhaka.

\section{MATERIALS AND METHODS}

Sample collection and processing. A total of 10 milk and milk products were collected aseptically from different shops within the city of Dhaka maintaining the standard procedure of sampling (1). Samples were transported immediately (approximately within 1 hour) to the laboratory for microbiological analysis. Prior to the estimation of bacterial and fungal load, samples were subjected serial dilutions up to $10^{-2}$

Microbiological analyses. For the enumeration of total viable bacteria and fungi, an aliquot of $0.1 \mathrm{~mL}$ of each suspension was introduced onto the nutrient agar (NA) plates and Sabouraud dextrose agar (SDA) plates by means of spreading in order to isolate and quantify the total viable bacterial count (TVBC) and fungi, respectively (1). The NA plates were incubated at $37{ }^{\circ} \mathrm{C}$ for 18 to 24 hours and the SDA plates were incubated at $25^{\circ} \mathrm{C}$ for 48 to 72 hours, respectively. For the estimation of specific pathogenic bacteria, from the dilution of $10^{-2}$ of each sample, $0.1 \mathrm{~mL}$ of suspension was spread onto MacConkey agar, mannitol salt agar (MSA) and cetrimide agar media for the enumeration of Escherichia coli, Staphylococcus spp. and Pseudomonas spp., consecutively. All the plates were incubated at $37^{\circ} \mathrm{C}$ for 24 hours. Appearance of the typical colonies such as pink colonies on MacConkey agar, yellow colonies on MSA and colonies with greenish pigmentation on cetrimide agar was analytical for the growth of E. coli or Klebsiella spp., Staphylococcus spp. and Pseudomonas spp., consecutively (29).

Enrichment procedure. For the detection of Salmonella spp. and Vibrio spp., samples were subjected enrichment for isolation and identification of these bacteria (30). One $\mathrm{ml}$ sample was added to selenite cystein broth (SCB) and alkaline peptone water (APW), respectively, and incubated at $37^{\circ} \mathrm{C}$ for 6 hours, and then $0.1 \mathrm{~mL}$ from each of the enriched broth was spread over SalmonellaShigella agar (SSA) and thioglycollate citrate bile salt (TCBS). Appearance of small blackish colonies after incubation for 24 hours at $37^{\circ} \mathrm{C}$ was indicative of the presence of Salmonella spp., while the large $(2-4 \mathrm{~mm})$ and slightly flattened, yellow colonies on the TCBS agar denoted the presence of Vibrio spp. Finally the confirmative biochemical tests were conducted to ensure the identity of the isolates $(29,30)$

Study of antibiogram. Isolated E. coli, Vibrio spp., Pseudomonas spp. and Staphylococcus aureus were subjected to antibiotic susceptibility assay against different groups of antibiotics in vitro by the Kirby-Bauer method (31). Drug resistance was observed against Penicillin $(10 \mu \mathrm{g})$, amoxicillin $(10 \mu \mathrm{g})$, Impenem $(10 \mu \mathrm{g})$, cefixime $(5 \mu \mathrm{g})$, Chloramphenicol $(30 \mu \mathrm{g})$, gentamicin $(10$ $\mu \mathrm{g})$; ciprofloxacin $(5 \mu \mathrm{g})$, sulphamethoxazole-trimethoprim $(25 \mu \mathrm{g})$, Vancomycin $(30 \mu \mathrm{g})$, azithromycin $(15 \mu \mathrm{g})$, Erythromycin $(15 \mu \mathrm{g})$. From overnight culture plate, a small portion of a fresh colony was transferred to Muller-Hinton broth and incubated at $37{ }^{\circ} \mathrm{C}$ for 4 to $5 \mathrm{hrs}$ until the growth reached to the equivalent turbidity standard of McFarland ( 0.5 standards). Muller- Hinton agar plates were seeded properly by spreading the inocula using sterile cotton swab. Discs (OXOID, UK) were placed gently at a proportionate distance from each other using a sterile needle. The plates were then incubated overnight at $37{ }^{\circ} \mathrm{C}$ and zones of inhibition (if any) were measured and interpreted as susceptible, intermediate and resistant (32).

\section{RESULTS AND DISCUSSION}

In the field of food microbiology sector in Bangladesh, while lots of works regarding food safety and security issues have been addressed; the specific identification strategy of microbial contaminants in the milk and milk products is still in its infancy $(1,8,14,26$, 33-36). Nevertheless, a few earlier researches reported that microbial contamination in milk and milk products could take place from three principal sources: inside the udder; the exterior of the udder and the surface of milk handling; and storage equipment $(15,37)$.

Current investigation also showed a scenario of huge microbial contamination in most of the samples. All samples were found to harbor the total viable bacteria and, were biochemically identified (Tables $1 \& 2$ ). Although $E$. coli, Salmonella spp. and Shigella spp. were not found in any sample, 6 samples were found to be contaminated with Klebsiella spp. $\left(10^{2} \mathrm{cfu} / \mathrm{mL}\right)$, belonging to the same family. Staphylococcus spp. were found in approximately about half (9) of the samples in a range of $10^{2}-10^{3} \mathrm{cfu} / \mathrm{mL}$. On the other hand, Vibrio spp. and Pseudomonas spp. were present in 9 and 7 samples, respectively in an average of $10^{2} \mathrm{cfu} / \mathrm{mL}$ (Table 1 ).

In this study, all the pathogenic isolates showed multidrug resistance (MDR) phenotype (Table 3). Isolates of Vibrio spp. and Pseudomonas spp. were found to be highly resistant $(88.88 \%)$ against all the used antibiotics except imipenem. Staphylococcus aureus isolates were found to be resistant against 8 different antibiotics and sensitive to ciprofloxacin, gentamicin and imipenem. Klebsiella spp. was found to be susceptible towards imipenem, gentamicin, erythromycin and chloramphenicol, respectively (Table 3 ). Results of this study showed a close link with previous study conducted by Marjan et al. (1). The research group showed that all the pathogenic isolates exhibited the MDR phenotype. Overall, according to the current study results, the presence of microorganisms in the studied samples is sufficiently indicative of severe health risk upon consumption of the dairy products tested unless appropriate microbiological measures are not taken. Sufficient legislative actions are thus of major clinical significance.

\section{CONCLUSION}

In cohort with the previous study findings on the microbiological analysis of milk and milk products carried out in the same laboratory, present study revealed the presence of a range of pathogenic bacteria which were of public health significance. Maintenance of proper hygiene during handling and processing of milk products as well as proper application of sterilization procedure such as pasteurization and UHT could ensure food quality and most importantly consumers' safety.

\section{ACKNOWLEDGMENTS}

Authors thank Stamford University Bangladesh for the logistic and financial supports to conduct the study. 
TABLE 1. Prevalence of pathogenic microorganisms in Milk and milk products

\begin{tabular}{|c|c|c|c|c|c|c|c|c|}
\hline Sample name & $\begin{array}{c}\text { TVB } \\
\text { (cfu/mL) }\end{array}$ & $\begin{array}{l}\text { Total fungal } \\
\text { count }\end{array}$ & $\begin{array}{c}\text { E. coli } \\
\text { (cfu/mL) }\end{array}$ & $\begin{array}{c}\text { Klebsiella } \\
\text { spp. } \\
(\mathrm{cfu} / \mathrm{mL})\end{array}$ & $\begin{array}{l}\text { Fecal } \\
\text { Coliform } \\
\text { count } \\
(\mathrm{cfu} / \mathrm{mL})\end{array}$ & $\begin{array}{c}\text { Pseudomonas } \\
\text { spp. } \\
\text { (cfu/mL) }\end{array}$ & $\begin{array}{c}\text { Staphylococcus } \\
\text { spp. } \\
\text { (cfu/mL) }\end{array}$ & $\begin{array}{c}\text { Vibrio } \\
\text { spp. } \\
\text { (cfu/mL) }\end{array}$ \\
\hline $\begin{array}{c}\text { Sweetened } \\
\text { yogurt }\end{array}$ & $1.20 \times 10^{2}$ & $2.0 \times 10^{2}$ & 0 & $2.0 \times 10^{2}$ & 0 & Nil & Nil & $3.0 \times 10^{2}$ \\
\hline $\begin{array}{c}\text { Sweetened } \\
\text { yogurt }\end{array}$ & $3.4 \times 10^{2}$ & $1.65 \times 10^{2}$ & 0 & $9.0 \times 10^{2}$ & 0 & Nil & Nil & Nil \\
\hline $\begin{array}{l}\text { Matta } \\
\text { UHT }\end{array}$ & $4.0 \times 10^{2}$ & $8.5 \times 10^{2}$ & 0 & 0 & 0 & $8.2 \times 10^{2}$ & Nil & Nil \\
\hline $\begin{array}{c}\text { Strawberry } \\
\text { Yogurt Milk }\end{array}$ & $8.0 \times 10^{2}$ & $9.0 \times 10^{2}$ & 0 & 0 & 0 & $7.0 \times 10^{2}$ & $9.0 \times 10^{2}$ & $2.8 \times 10^{2}$ \\
\hline Cream & $1.35 \times 10^{2}$ & $3.0 \times 10^{2}$ & 0 & 0 & 0 & $2.4 \times 10^{2}$ & Nil & $1.1 \times 10^{2}$ \\
\hline Cream & $2.20 \times 10^{2}$ & $2.20 \times 10^{2}$ & 0 & 0 & 0 & $1.6 \times 10^{2}$ & $2.4 \times 10^{2}$ & $2.6 \times 10^{2}$ \\
\hline Sour card & $2.60 \times 10^{2}$ & $8.0 \times 10^{2}$ & 0 & 0 & 0 & Nil & Nil & $2.7 \times 10^{2}$ \\
\hline Sour Card & $8.5 \times 10^{1}$ & $2.20 \times 10^{2}$ & 0 & $6.0 \times 10^{2}$ & 0 & Nil & Nil & $2.3 \times 10^{2}$ \\
\hline Butter & $2.10 \times 10^{2}$ & $1.60 \times 10^{2}$ & 0 & 0 & 0 & $1.7 \times 10^{2}$ & Nil & $3.0 \times 10^{2}$ \\
\hline Butter & $4.0 \times 10^{2}$ & $3.4 \times 10^{2}$ & 0 & 0 & 0 & $3.0 \times 10^{2}$ & Nil & Nil \\
\hline $\begin{array}{l}\text { Pasteurized } \\
\text { milk }\end{array}$ & $1.2 \times 10^{3}$ & $1.0 \times 10^{2}$ & 0 & $2.0 \times 10^{2}$ & 0 & 0 & $1.0 \times 10^{2}$ & 0 \\
\hline $\begin{array}{l}\text { Pasteurized } \\
\text { milk }\end{array}$ & $2.9 \times 10^{3}$ & $4.5 \times 10^{2}$ & 0 & $9.0 \times 10^{2}$ & 0 & 0 & 0 & $8.0 \times 10^{2}$ \\
\hline UHT milk & $2.6 \times 10^{4}$ & $3.0 \times 10^{3}$ & 0 & 0 & 0 & 0 & 0 & 0 \\
\hline UHT milk & $2.4 \times 10^{3}$ & $8.0 \times 10^{2}$ & 0 & 0 & 0 & 0 & 0 & 0 \\
\hline Mango milk & $6.0 \times 10^{2}$ & $5.0 \times 10^{2}$ & 0 & 0 & 0 & 0 & $3.0 \times 10^{2}$ & 0 \\
\hline Mango milk & $2.8 \times 10^{4}$ & $1.2 \times 10^{3}$ & 0 & 0 & 0 & $5.0 \times 10^{2}$ & $1.0 \times 10^{3}$ & $4.0 \times 10^{2}$ \\
\hline $\begin{array}{l}\text { Chocolate } \\
\text { milk }\end{array}$ & $2.0 \times 10^{4}$ & $7.0 \times 10^{3}$ & 0 & 0 & 0 & 0 & $4.0 \times 10^{2}$ & 0 \\
\hline $\begin{array}{l}\text { Chocolate } \\
\text { milk }\end{array}$ & $1.0 \times 10^{4}$ & $1.0 \times 10^{2}$ & 0 & $6.0 \times 10^{2}$ & 0 & 0 & $8.0 \times 10^{3}$ & 0 \\
\hline Normal Lassie & $1.8 \times 10^{3}$ & $2.0 \times 10^{2}$ & 0 & 0 & 0 & 0 & $1.0 \times 10^{2}$ & 0 \\
\hline Mango lassie & $2.6 \times 10^{2}$ & $2.0 \times 10^{2}$ & 0 & 0 & 0 & 0 & $4.0 \times 10^{2}$ & 0 \\
\hline
\end{tabular}

*Microbial limit $(38,39,40)$

Pasteurized Milk: SPC $5 \times 10^{5} \mathrm{cfu} / \mathrm{g}$, Coliform- $5 \mathrm{cfu} / \mathrm{mL}$

UHT Milk: Commercially sterile

Milk product: SPC $5 \times 10^{5} \mathrm{cfu} / \mathrm{g}$, Coliform-100 cfu/g

TABLE 2. Confirmative biochemical tests for the isolates

\begin{tabular}{|c|c|c|c|c|c|c|c|c|c|c|c|}
\hline & $\begin{array}{l}\text { Assumed } \\
\text { Organism }\end{array}$ & $\frac{\vec{E}}{\infty}$ & $\stackrel{\Xi}{\Xi}$ & 㺃 & 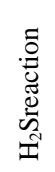 & $\begin{array}{l}\overrightarrow{\tilde{a}} \\
\stackrel{\Xi}{0} \\
\stackrel{0}{0} \\
\stackrel{\Xi}{\Xi}\end{array}$ & $\stackrel{\mathscr{v}}{\ddot{d}}$ & 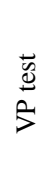 & 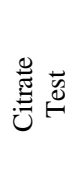 & 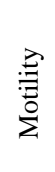 & 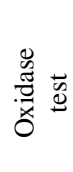 \\
\hline & Klebsiella spp. & $\mathrm{Y}$ & $\mathrm{Y}$ & - & - & - & - & - & - & - & + \\
\hline & Pseudomonas spp. & A & $\mathrm{A}$ & - & - & - & - & - & + & - & - \\
\hline & Staphylococcus spp. & $\mathrm{Y}$ & $\mathrm{R}$ & + & + & - & + & - & + & + & - \\
\hline & Vibrio spp. & $\mathrm{Y}$ & $\mathrm{Y}$ & - & - & + & + & - & + & + & + \\
\hline TSI & Triple Sugar Iron Test & & & & & & & & & & \\
\hline $\mathrm{Y}$ & Yellow (Acid) & & & & & & & & & & \\
\hline $\mathrm{R}$ & Red (Alkaline) & & & & & & & & & & \\
\hline MR & Methyl red & & & & & & & & & & \\
\hline VP & Voges-Proskauer & & & & & & & & & & \\
\hline A & Acidic reaction & & & & & & & & & & \\
\hline $\mathrm{K}$ & Alkaline reaction & & & & & & & & & & \\
\hline ND & Not done & & & & & & & & & & \\
\hline+ & Positive & & & & & & & & & & \\
\hline- & Negative & & & & & & & & & & \\
\hline
\end{tabular}


TABLE 3. Study of antibiogram

\begin{tabular}{ccccccccc}
\hline Antibiotics & \multicolumn{7}{c}{ Pathogenic Isolates } \\
\cline { 2 - 9 } & $\begin{array}{c}\text { Klebsiella spp. } \\
\mathrm{N}=6\end{array}$ & \multicolumn{2}{c}{$\begin{array}{c}\text { Vibrio spp. } \\
\mathrm{N}=9\end{array}$} & $\begin{array}{c}\text { Staphylococcus aureus } \\
\mathrm{N}=9\end{array}$ & $\begin{array}{c}\text { Pseudomonas spp. } \\
\mathrm{N}=7\end{array}$ \\
\cline { 2 - 9 } & $\mathrm{R}$ & $\mathrm{S}$ & $\mathrm{R}$ & $\mathrm{S}$ & $\mathrm{R}$ & $\mathrm{S}$ & $\mathrm{R}$ & $\mathrm{S}$ \\
\hline CIP & $83.33 \%$ & $16.66 \%$ & $88.88 \%$ & $11.11 \%$ & $55.55 \%$ & $44.44 \%$ & $85.71 \%$ & $14.28 \%$ \\
CEF & $83.33 \%$ & $16.66 \%$ & $88.88 \%$ & $11.11 \%$ & $11.11 \%$ & $88.88 \%$ & $71.42 \%$ & $28.57 \%$ \\
AML & $83.33 \%$ & $16.66 \%$ & $55.55 \%$ & $44.44 \%$ & $88.88 \%$ & $11.11 \%$ & $85.71 \%$ & $14.28 \%$ \\
IPM & $16.66 \%$ & $83.33 \%$ & $88.88 \%$ & $11.11 \%$ & $11.11 \%$ & $88.88 \%$ & $14.28 \%$ & $85.71 \%$ \\
PEN & $83.33 \%$ & $16.66 \%$ & $66.66 \%$ & $33.33 \%$ & $88.11 \%$ & $11.11 \%$ & $85.71 \%$ & $14.28 \%$ \\
TMP-SUL & $50 \%$ & $50 \%$ & $66.66 \%$ & $33.33 \%$ & $66.66 \%$ & $33.33 \%$ & $71.42 \%$ & $28.57 \%$ \\
GEN & $16.66 \%$ & $83.33 \%$ & $88.88 \%$ & $11.11 \%$ & $88.88 \%$ & $11.11 \%$ & $71.42 \%$ & $28.57 \%$ \\
AZI & $83.33 \%$ & $16.66 \%$ & $11.11 \%$ & $88.88 \%$ & $88.88 \%$ & $101.11 \%$ & $85.71 \%$ & $14.28 \%$ \\
ERY & $33.33 \%$ & $66.66 \%$ & $11.11 \%$ & $88.88 \%$ & $88.88 \%$ & $11.11 \%$ & $85.71 \%$ & $14.28 \%$ \\
CHL & $33.33 \%$ & $66.66 \%$ & $88.88 \%$ & $11.11 \%$ & $55.55 \%$ & $44.44 \%$ & $71.42 \%$ & $28.57 \%$ \\
VAN & $83.33 \%$ & $16.66 \%$ & $11.11 \%$ & $88.88 \%$ & $66.66 \%$ & $33.33 \%$ & $85.71 \%$ & $14.28 \%$ \\
\hline
\end{tabular}

$\mathrm{CIP}=$ ciprofloxacin $(5 \mu \mathrm{g}) ; \mathrm{CEF}=$ Cefixime $(5 \mu \mathrm{g}) ; \mathrm{AML}=$ Amoxicillin $(10 \mu \mathrm{g}) ; \mathrm{IPM}=$ Imipenm $(10 \mu \mathrm{g}) ;$ Penicillin $=(10 \mu \mathrm{g}) \mathrm{TMP}-\mathrm{SUL}=$ Sulfamethoxazole, $(25 \mu \mathrm{g}) ; \mathrm{GEN}=$ Gentamicin $(10 \mu \mathrm{g}) ; \mathrm{AZI}=$ Azithromycin $(15 \mu \mathrm{g}) ;$ ERY = Erythromycin $(15 \mu \mathrm{g})$; CHL $=$ Chloramphenicol $(30$ $\mu \mathrm{g}) ; \mathrm{VAN}=$ Vancomycin $(30 \mu \mathrm{g}) ; \mathrm{ND}=$ Not Done; $\mathrm{R}=$ Resistant; $\mathrm{S}=$ Sensitive

\section{REFERENCES}

1. Marjan S, Das KK, Munshi SK, Noor R. 2014. Drug-resistant bacterial pathogens in milk and some milk products. Nutrition \& Food Science. 44 (3): 241-248.

2. Aebi M, van den Borne BH, Raemy A, Steiner A, Pilo P, Bodmer M, et al. 2015. Mycoplasma bovis infections in Swiss dairy cattle: a clinical investigation. Acta Vet. Scand. 57 (1): 10.

3. Mansouri-Najand L, Rezaii Z. 2015. Risk factors affecting chemical and bacteriological quality of bulk tank milk in Kerman, Iran. Vet. Res. Forum. 6 (1): 79-82.

4. Hamiroune M, Berber A, Boubekeur S. 2014. Contribution to the study of staphylococcus contamination of cows' milk on a number of farms in Algiers: its impact on human health. Rev. Sci. Tech. 33 (3): 1035-41, 1027-34.

5. Guimarães FF, Nóbrega DB, Richini-Pereira VB, Marson PM, de Figueiredo Pantoja JC, Langoni H. 2013. Enterotoxin genes in coagulase-negative and coagulase-positive staphylococci isolated from bovine milk. J. Dairy Sci. 96 (5): 2866-72.

6. Quigley L, O'Sullivan O, Stanton C, Beresford TP, Ross RP, Fitzgerald GF, et al. 2013. FEMS Microbiology Reviews. 37 (5): 664 698.

7. Piessens V, Van Coillie E, Verbist B, Supré K, Braem G, Van Nuffel A, et al. 2011. Distribution of coagulase-negative Staphylococcus species from milk and environment of dairy cows differs between herds. J. Dairy Sci. 94 (6): 2933-44

8. Uddin MA, Haque HMM, Noor R. 2011. Isolation and Identification of Pathogenic Escherichia coli, Klebsiella spp. And Staphylococcus spp. in Raw Milk Samples Collected from Different Areas of Dhaka City, Bangladesh. Stamford J. Microbiol. 1 (1): 19-23.

9. Zucali M, Bava L, Tamburini A, Brasca M, Vanoni L, Sandrucci A. 2011. Effects of season, milking routine and cow cleanliness on bacterial and somatic cell counts of bulk tank milk. J. Dairy Res. 78 (4): 436-41.

10. Yu J, Wang W, Menghe B, Jiri MT, Wang HM, Liu VVJ, et al. 2011. Diversity of lactic acid bacteria associated with traditional fermented dairy products in Mongolia. J. Dairy Sci. 94: 3229-3241.

11. Quigley L, O'Sullivan O, Beresford TP, Ross RP, Fitzgerald GF, Cotter PD. 2012. High-throughput sequencing for detection of subpopulations of bacteria not previously associated with artisanal cheeses. Appl. Environ. Microbiol. 78: 5717-5723.

12. Premalatha M, Dhasarathan P. 2011. Probiotic action of Lactobacillus isolated from the milk sample against some human pathogens. Res. J. Immunol. 4: 31-37.

13. Quigley L, O'Sullivan O, Beresford TP, Ross RP, Fitzgerald GF, Cotter PD. 2011. Molecular approaches to analysing the microbial composition of raw milk and raw milk cheese. Int. J. Food Microbiol. 150: 81-94

14. Yasmin S, Parveen S, Munna MS, Noor R. 2015. Detection of Salmonella spp. and microbiological analysis of milk and milk based products available within Dhaka Metropolis. Bangladesh. British
Microbiology Research Journal. 5 (6): 474-480.

15. Afroz H, Sultana F, Fakruddin M, Kamrunnahar, Khan ZUM, Datta S 2013. Isolation of Escherichia coli and Staphylocccus aureus from full cream power milk sold under market conditions at Dhaka, Bangladesh and their antibiotic susceptibility. J. Adv. Sci Res. 4 (3): 27-31.

16. McIntyre L, Wilcott L, Naus M. 2015. Listeriosis outbreaks in British Columbia, Canada, caused by soft ripened cheese contaminated from environmental sources. Biomed Res. Int. 2015: 131623.

17 Tadesse G, Gebremedhin EZ. 2015. Prevalence of Salmonella in raw animal products in Ethiopia: a meta-analysis. BMC Res. Notes. 8 (1): 163

18. Saadat RY, Fooladi IAA, Shapouri R, Hosseini MM, Deilami Khiabani Z 2014. Prevalence of enterotoxigenic Staphylococcus aureus in organic milk and cheese in Tabriz, Iran. Iran J. Microbiol. 6 (5): 345-9.

19. Verdier-Metz I, Gagne G, Bornes S, Monsallier F, Veisseire P, Delbes-Paus C et al. 2012. Cow teat skin, a potential source of diverse microbial populations for cheese production. Appl. Environ. Microbiol. 78: 326-333.

20. Vacheyrou M, Normand AC, Guyot P, Cassagne C, Piarroux R, Bouton $Y$ 2011. Cultivable microbial communities in raw cow milk and potentia transfers from stables of sixteen French farms. Int. J. Food Microbiol. 146: 253-262.

21. Braem G, De Vliegher S, Verbist B, Heyndrickx M, Leroy F, De Vuyst L 2012. Culture-independent exploration of the teat apex microbiota of dairy cows reveals a wide bacterial species diversity. Vet. Microbiol. 157: 383-390.

22. Monsallier F, Verdier-Metz I, Agabriel C, Martin B, Montel MC. 2012 Variability of microbial teat skin flora in relation to farming practices and individual dairy cow characteristics. Dairy Sci. Technol. 92: 265-278.

23. Sharma D, Malik A. 2012.Incidence and prevalence of antimicrobial resistant Vibrio cholerae from dairy farms. African Journal of Microbiology Research. 6 (25): 5331-5334.

24. Coloe PJ, Van TTH, Moutafis G, LinhThuoc Tran LT. 2007. Antibiotic Resistance in Food-Borne Bacterial Contaminants in Vietnam. Appl. Environ. Microbiol. 73 (24): 7906-7911.

25. Teuber M. 2001. Veterinary use and antibiotic resistance. Curr. Opin. Microbiol. 4: 493-499.

26. Noor R, Uddin MA, Haq MA, Munshi SK, Acharjee M, Rahman MM 2013. Microbiological study of vendor and packed fruit juices locally available in Dhaka city, Bangladesh. Int. Food Res. J. 20 (2): 1011-1015.

27. Noor R, Munna MS. 2015. Emerging diseases in Bangladesh: current microbiological research. Tzu Chi Medical Journal. 27 (2): 49-53.

28. Sommer JU, Schmitt A, Heck M, Schaeffer EL, Fendt M, Zink M. 2010 Differential expression of presynaptic genes in a rat model of postnatal hypoxia: relevance to schizophrenia. Eur. Arch. Psychiatry Clin. Neurosci. 260: S81-S89.

29. Cappuccino JG, Sherman N. 1996. Microbiology: A laboratory manual. The Benjamin/Cummings Publishing Co., Menlo Park, California.

30. Rahman F, Noor R. 2012. Prevalence of pathogenic bacteria in common salad vegetables of Dhaka Metropolis. Bangladesh Journal of Botany. 41 (2): 159 162

31. Bauer AW, Kirby WMM, Sherris JC, Turck M. 1966.Antibiotic susceptibility testing by a standardized single disk method. American Journal of Clinical Pathology. 45 (4): 493-496. 
32. Ferraro MJ, Craig WA, Dudley MN. 2001. Performance Standards for Antimicrobial Susceptibility Testing, NCCLS Informational Supplement NCCLS, Wayne, PA.

33. Ahmed T, Baidya S, Sharma BC, Malek M, Das KK, Acharjee M, et al. 2013. Identification of drug-resistant bacteria among export quality shrimp samples in Bangladesh. Asian J Microbiol Biotech Env Sci. 15 (4): 31-36.

34. Sultana S, Tarafder GH, Siddiqui TA, Shaha BC, Walliullah M, Ahmed T et al. 2014. Microbiological quality analysis of shrimps collected from local market around Dhaka city. Int. Food Res. J. 21 (1): 33-38.

35. Fatema N, Acharjee M, Noor R. 2013. Microbiological profiling of imported apples and demonstration of bacterial survival capacity through in vitro challenge test. Am. J. Microbiol. Res. 1 (4): 98- 04

36. Sarker N, Islam S, Hasan M, Kabir F, Uddin MA, Noor R. 2013. Use of multiplex PCR assay for detection of diarrheagenic Escherichia coli in street vended food items. Am. J. Lif. Sci. 1 (6): 267-272.
37. Bramley AJ, McKinnon CH. 1990. The microbiology of raw milk. Elsevier Applied Sci., London.

38. Australian Dairy Authorities' Standards Committee (ADASC). 2000. Minimum sampling guidelines for dairy products. Available from http://www.dairysafe.vic.gov.au/documents/Minimum\%20Sampling\%20Guid elines\%20for\%20Dairy\%20Products.pdf. Accessed May 27, 2003.

39. Codex Alimentarius Commission (CAC). 1983. Recommended international code of hygienic practice for dried milk. CAC/RPC 31. Available from ftp://ftp.fao.org/codex/standard/en/CXP_031e.pdf. Accessed May 27, 2003.

40. European Commission (EC). 2001. Overview of Microbiological Criteria for Foodstuffs in Community Legislation in Force. Available from http://europa.eu.int/comm/food/fs/sfp/mr/mr_crit_en.pdf. Accessed April 11, 2003. 